\title{
Resistance of Kansas Sclerotinia homoeocarpa Isolates to Thiophanate-Methyl and Determination of Associated $\beta$-Tubulin Mutation
}

\begin{abstract}
Jesse C. Ostrander, Richard B. Todd, and Megan M. Kennelly, Department of Plant Pathology, Kansas State University, Manhattan 66506
\end{abstract}
Accepted 7 April 2014. Published 6 June 2014.

\section{ABSTRACT}

Ostrander, J. C., Todd, R. B., and Kennelly, M. M. 2014. Resistance of Kansas Sclerotinia homoeocarpa isolates to thiophanate-methyl and determination of associated $\beta$-tubulin mutation. Plant Health Progress doi:10.1094/PHP-RS-13-0120.

Eighty-two isolates of Sclerotinia homoeocarpa from 12 sites in Kansas were evaluated for in vitro sensitivity to the methyl benzimidazole carbamate (MBC) fungicide thiophanate-methyl at the discriminatory dose of $10 \mu \mathrm{g} / \mathrm{ml}$. Seventeen isolates were sensitive to thiophanate-methyl and the remaining isolates were resistant. Of the 65 isolates from golf course putting greens, two isolates were sensitive and the remaining 63 isolates were resistant. Six resistant and five sensitive isolates were also evaluated in greenhouse assays on fungicide-treated plants. The isolates

\section{INTRODUCTION}

Dollar spot, caused by Sclerotinia homoeocarpa, is a common disease of cultivated turfgrasses $(4,27)$. The pathogen has a wide host range including cool season-grasses, such as creeping bentgrass (Agrostis stolonifera), Kentucky bluegrass (Poa pratensis), annual bluegrass (Poa annua), and fescues (Festuca spp.), as well as warm-season grasses, such as bermudagrass (Cynodon dactylon) and buffalograss (Buchloë dactyloides). Dollar spot is a frequent problem in creeping bentgrass putting greens and fairways. In turfgrass cut at putting green height $(2.5$ to $4.0 \mathrm{~mm}$ ), the disease causes tan, sunken infection centers that are 2 to $5 \mathrm{~cm}$ in diameter and in higher-cut turf the infection centers usually range from 2 to $15 \mathrm{~cm}$ in diameter (4,27). Dollar spot management in golf courses relies heavily on the application of fungicides. Several classes of fungicides are registered for dollar spot control, including contact/multisite materials as well as systemic fungicides in the methyl benzimidazole carbamate (MBC), demethylation inhibitor (DMI), succinate-dehydrogenase inhibitor (SDHI), and dicarboximide groups $(14,29)$.

Resistance of $S$. homoeocarpa to various fungicides has been reported in North America. Specifically, resistance to MBC fungicides was first reported in the 1970s in isolates from several areas in the eastern and midwestern United States (30) and since then has been documented in numerous other locations $(1,2,5,10,25)$. Sensitivity of $S$. homoeocarpa isolates to MBC fungicides has not been examined in Kansas. Though superintendents generally utilize a variety of fungicide classes and active ingredients, the MBC fungicide thiophanate-methyl is a component of application regimes both as a stand-alone product and in combinations.

Corresponding author: Megan Kennelly. Email: Kennelly@ksu.edu that were sensitive to thiophanate-methyl in vitro did not cause any disease on thiophanate-methyl-treated plants, and those that were resistant in vitro caused blighting on treated plants equivalent to the nontreated controls. The entire $\beta$-tubulin gene was sequenced for four resistant and four sensitive isolates. The resistant isolates all harbored a substitution of alanine for glutamic acid at codon 198 (E198A). These results provide a starting point for further surveys and monitoring of fungicide sensitivity.
MBC fungicides, such as thiophanate-methyl, inhibit the production of microtubules by binding to the $\beta$-tubulin protein, thus interfering with mitosis and cell growth. Resistance to MBC fungicides is conferred by single nucleotide mutations in the $\beta$ tubulin gene that cause an amino acid substitution preventing binding at the target site $(15,22)$. Resistance has been associated with mutations in the $\beta$-tubulin gene in many fungal species including Venturia inaequalis, Monilinia fructicola, Monilinia laxa, Colletotrichum cereale, Cladobotryum dendroides, and others $(3,4,15,16,17,20,31,32)$. Most of these mutations have involved the 198th codon, although the specific amino acid substitution varies, with changes from the wild-type glutamic acid to alanine (E198A), glutamine (E198Q), glycine (E198G), lysine (E198K), or valine (E198V) (15). In laboratory induced mutants as well as in field isolates, mutations associated with resistance to MBC fungicides have also occurred at the 6th (H6Y), 50th (Y50C), 167th (F167Y), 200th (F200Y) and 240th (L240F) codons $(3,11,13,15,17)$. In previous work (13), a mutation leading to a change of glutamic acid to lysine at codon 198 (E198K) was associated with MBC resistance in many species of fungi, including one isolate of $S$. homoeocarpa. The primers in that study were designed to amplify codons 167-241, omitting other regions of the gene with potential mutations associated with resistance. Another study (6) focusing on population structure of S. homoeocarpa, including isolates sensitive and resistant to thiophanate-methyl, utilized conserved primers $\mathrm{Bt} 2 \mathrm{a}$ and $\mathrm{Bt} 2 \mathrm{~b}$ (7) which amplify codons $12-127$ of the $\beta$-tubulin gene. Sequences for resistant and sensitive isolates were identical, indicating that the mutation associated with resistance was not in that region (6).

Fungicide performance can be reduced based on application timing, application water volume, nozzle selection, accurate identification of the disease, and other factors $(12,19,26,28)$. Fungicide resistance is another consideration. With thiophanatemethyl, the qualitative (bimodal) nature of resistance can lead to control failures in the field. In previous work, significant increases were observed in the frequency of thiophanate-methyl 
resistance in a previously unexposed population after just two applications (9).

The objectives of this study were to determine the sensitivity of 82 Kansas $S$. homoeocarpa isolates to thiophanate-methyl using in vitro methods, to compare the results to in planta sensitivity for a subset of isolates, and to sequence the entire $\beta$-tubulin gene of several resistant and sensitive isolates to determine mutations associated with resistance.

\section{COLLECTION, ISOLATION, AND STORAGE OF SCLEROTINIA HOMOEOCARPA}

Plugs of turfgrass 3 to $10 \mathrm{~cm}$ in diameter, containing individual dollar spot infection centers were collected from 12 sites in Kansas from 2007 to 2013 (Table 1), some of which were previously assayed for sensitivity to boscalid (8). Sclerotinia homoeocarpa was isolated, identified, and hyphal tipped as described previously (8). Millet grain inoculum was prepared as described previously $(8,10,21)$.

\section{IN VITRO SENSITIVITY ASSAYS FOR THIOPHANATE- METHYL}

Based on preliminary results testing 7 isolates three times each, and prior research $(1,10), 10 \mu \mathrm{g} / \mathrm{ml}$ was selected as a single discriminatory dose to distinguish sensitive and resistant isolates. The remaining 75 isolates were each tested twice at 0 and $10 \mu \mathrm{g} / \mathrm{ml}$ with one petri dish per concentration in each experimental run. One grain of colonized frozen millet per isolate was placed onto the center of a 9-cm petri dish of unamended $1 / 4$ PDA and incubated for 3 to 5 days. Then, one 4-mm plug of the starter culture of each isolate was placed inverted onto the center of one $9-\mathrm{cm}$ petri dish of $1 / 4$ PDA amended with commercially available thiophanate-methyl [41.25\% a.i., Cleary's 3336F (Cleary Chemical Corp., Dayton, NJ)]. The fungicide was suspended in sterile, distilled water and added to autoclaved, partially cooled $1 / 4$ PDA to a final concentration of $10 \mu \mathrm{g} / \mathrm{ml}$ at a volume of $25 \mathrm{ml}$ media per petri dish. Cultures were incubated at $20-24^{\circ} \mathrm{C}$ for 3 days, then colony size was determined by measuring two perpendicular diameters and subtracting the size of the 4-mm plug. Relative mycelial growth was calculated as the diameter on amended media divided by the diameter on unamended media and multiplied by 100 .

Of the 82 isolates tested, 17 were sensitive to thiophanatemethyl with no growth at the discriminatory concentration of $10 \mu \mathrm{g} / \mathrm{ml}$ (Table 1). Relative growth of the resistant isolates on the discriminatory concentration was always $>85 \%$ of the unamended control. Sixty-five of the isolates were collected from golf course putting greens. Of those, only two were sensitive to thiophanate-methyl. These results are similar to studies in other states and regions that detected a high frequency of resistance $(1,9,10,25)$. Detailed application histories were not available, but most golf courses had some history of applying thiophanatemethyl ranging from rare (once per year or less) to occasional (23 times per year). Site AVPB had applied thiophanate-methyl once since the 1990s, and WCGC had no record of applying it in any recent years. The other sensitive isolates originated from two Kentucky bluegrass tees, a Kentucky bluegrass fairway, a buffalograss home lawn, and various research plots at the KSU Rocky Ford Turfgrass Center. In general, those sites have little to no history of fungicide use.

\section{IN PLANTA ASSAYS}

Fungicide sensitivity was determined in greenhouse assays using eleven isolates, five that were sensitive [sources: AVPB green, DCCC tee, DCCC fairway, NCLWN, and RFTC (Table 1)], and six that were resistant [sources: one isolate each from OSWT green, WCGC green, WCGC fairway, and three from different putting greens at QRCC (Table 1)] to thiophanatemethyl in vitro. Creeping bentgrass cultivar 'Crenshaw' was planted into 8-cm-square pots containing SunGro Metro-Mix 360 (Sun Gro Horticulture, Vancouver, Canada), a peat moss, vermiculite, bark mixture, at a rate of $0.12 \mathrm{~g}$ seed/pot. Pots were placed under intermittent mist for 10 days then placed in a greenhouse and plant height was maintained at $2 \mathrm{~cm}$ by clipping with scissors three times per week. Assays were initiated 33 days

\begin{tabular}{|c|c|c|c|c|}
\hline \multirow[b]{2}{*}{ Site $^{x}$} & \multicolumn{3}{|c|}{$\begin{array}{l}\text { TABLE } 1 \\
\begin{array}{l}\text { Source, year of collection, and thiophanate-methyl in vitro sensitivity } \\
\text { of Sclerotinia homoeocarpa isolates from Kansas. }\end{array}\end{array}$} & \multirow[b]{2}{*}{$\begin{array}{l}\text { \# Isolates sensitive to } \\
\text { thiophanate-methylz }\end{array}$} \\
\hline & $\begin{array}{c}\text { Turf stand } \\
\text { informationy }\end{array}$ & Collection year(s) & Number of isolates & \\
\hline AVPB & $1 \mathrm{CBG}$ & 2007 & 1 & 1 \\
\hline DCCC & $2 \mathrm{KBT}, 1 \mathrm{KBF}$ & 2007 & 3 & 3 \\
\hline AVPV & Several CBG's & 2007 and 08 & 9 & 0 \\
\hline $\mathrm{CBHCC}$ & $1 \mathrm{CBG}$ & 2008 & 10 & 1 \\
\hline $\mathrm{CHCC}$ & Several CBG's & 2008 & 4 & 0 \\
\hline OSWT & Several CBG's & 2008 & 18 & 0 \\
\hline QRCC & Several CBG’s & 2008 & 14 & 0 \\
\hline WCGC & $1 \mathrm{CBG} \& 1 \mathrm{KBF}$ & 2007 & 2 & 0 \\
\hline NCLWN & buffalograss lawn & 2008 & 1 & 1 \\
\hline & bermudagrass fairway & 2013 & 1 & 1 \\
\hline & Buffalograss lawn & 2013 & 1 & 1 \\
\hline & $1 \mathrm{CBG}$ & 2013 & 1 & 0 \\
\hline TOTAL & & & 82 & 17 \\
\hline
\end{tabular}

$\mathrm{x}$ NCLWN is a home lawn and RFTC is the Rocky Ford Turfgrass Research Center at Kansas State University. All other sites are golf courses.

y $\mathrm{CBG}=$ creeping bentgrass putting green, $\mathrm{KBF}=$ Kentucky bluegrass fairway, $\mathrm{KBT}=$ Kentucky bluegrass tee

$\mathrm{z}$ Isolates were tested for thiophanate-methyl sensitivity in vitro using a concentration of $10 \mu \mathrm{g} / \mathrm{ml}$. 
after seeding in the first experiment and 40 days after seeding in the second experiment.

Plants were treated with thiophanate-methyl (Cleary's 3336 F) at the highest label rate, $6.1 \mathrm{~kg}$ a.i./ha, in a greenhouse using a $\mathrm{CO}_{2}$-powered hand-held spray boom equipped with one 8008EVS even-spray nozzle (Spraying Systems Co., Wheaton IL) at $207 \mathrm{kPa}$ in water equivalent to a field application of 825 liters/ha, for a final concentration of $7.4 \mathrm{mg}$ a.i./ml. Non-treated checks were sprayed with water. Plants were allowed to dry for 3 to $4 \mathrm{~h}$ prior to inoculation.

Plants were inoculated in the laboratory by placing one colonized millet seed (described above) into each of the 4 quadrants of the pot. Mock-inoculated plants receiving one seed per quadrant of sterile millet were included for each fungicide treatment. There were three replicate pots of each fungicideisolate combination. Plants were misted lightly with water using a small $\mathrm{CO}_{2}$-powered aerosol sprayer (Preval, Coal City, IL) and arbitrarily placed into $67 \times 41 \times 17 \mathrm{~cm}$ plastic containers (Sterilite Corp., Townsend, MA) for $48 \mathrm{~h}$ at $24^{\circ} \mathrm{C}$. The pots were then placed into a greenhouse for four cycles of $9 \mathrm{~h}$ ambient daylight conditions followed by misting, then $15 \mathrm{~h}$ overnight in the dark in moist boxes in the laboratory. After a final 24-h period in the greenhouse, disease severity was assessed by visually estimating the percentage of blighted tissue per pot. For each isolate, disease severity in the fungicide-treated plants was compared to the nontreated plants to give a relative severity score, calculated as disease severity in fungicide treatment divided by disease severity in non-treated control and multiplied by 100. In addition, for each isolate, a T-test was used to compare disease severity in the nontreated plants with disease severity in the treated plants (SAS Institute Inc., Cary, NC). The experiment was conducted twice. Results were consistent and data from the two experiments were combined.

None of the isolates that were designated as sensitive to thiophanate-methyl in the in vitro assays caused any blighting in the plants treated with thiophanate-methyl. The six isolates that were resistant to thiophanate-methyl in the in vitro assays caused disease severity in the thiophanate-methyl-treated plants not significantly different $(P>0.05)$ from non-treated controls, with relative severity always $>78 \%$. The in vitro thiophanate-methyl assay using one discriminatory concentration of $10 \mu \mathrm{g} / \mathrm{ml}$ corresponded to the in planta assays, consistent with prior greenhouse and field studies and the known bimodal resistance to MBC fungicides (10,30).

\section{SEQUENCE ANALYSIS OF THE $\beta$-TUBULIN GENE}

Four sensitive (three from DCCC and one from $\mathrm{CBHCC}$ ), and four resistant (two from $\mathrm{CBHCC}$, one from $\mathrm{MCC}$, and one from QRCC) isolates were chosen for sequencing of the entire $\beta$ tubulin gene (Table 1). For each isolate, a single piece of colonized millet was placed on a piece of circular cellophane, $80 \mathrm{~mm}$ in diameter, which was then placed on top of $1 / 4$ PDA in an $80 \mathrm{~mm}$ Petri dish. The colonies were allowed to grow for 7-14 days, or until the mycelium reached the edge of the dish. The cellophane was removed and placed, with aerial mycelium growth, into a laminar flow hood to dry for 7 days. Genomic DNA was extracted using a commercial kit (Easy-DNA kit, Life Technologies, Grand Island, NY) with minor modifications. Room temperature isopropanol was substituted for $-20^{\circ} \mathrm{C} 100 \%$ ethanol for DNA precipitation and $70 \%$ ethanol was substituted for $80 \%$ ethanol for the DNA wash. DNA preparations were stored at $-20^{\circ} \mathrm{C}$.

An unpublished genomic sequence contig (L. Tredway, personal communication) from $S$. homoeocarpa isolate
MB01 (23), sensitive to thiophanate-methyl, was used to identify the sequence of the $\beta$-tubulin gene. This nucleotide sequence was BLAST searched against the National Center for Biotechnology Information (NCBI) Microbes sequence database (http://blast.ncbi.nlm.nih.gov/Blast.cgi) to locate the $\beta$-tubulin gene within the contig. Serial Cloner 2.5

(http://serialbasics.free.fr) was used to identify start and stop codons and determine the $\beta$-tubulin gene structure by sequence homology with the known ascomycete $\beta$-tubulin sequences ben $A$ (AN1182) of Aspergillus nidulans and the $\beta$-tubulin gene (BC1G_00122) of Botryotinia fuckeliana (strain B05.10) $(19,25)$. Sequence searches of the contig from the reference isolate MB01 against the NCBI Microbes sequence database revealed a putative $\beta$-tubulin gene with sequence similarity to known ascomycete $\beta$ tubulin genes. The gene structure was deduced by sequence comparisons with the $\beta$-tubulin genes from $A$. nidulans and $B$. fuckeliana. The $S$. homoeocarpa $\beta$-tubulin gene was 1785 base pairs (bp) long, including seven exons and six introns (Fig. 1). Residues 6, 50, 165, 134, 198, 200, and 257, which are known to be involved in $\mathrm{MBC}$ resistance in other species, were conserved in the contig from isolate MB01. Isolate MB01 did not harbor any mutations in the $\beta$-tubulin sequence known to confer or be associated with $\mathrm{MBC}$ resistance.

Three pairs of PCR primers were designed to amplify overlapping PCR products for complete sequencing of the $S$. homoeocarpa $\beta$-tubulin gene for the four sensitive and four resistant Kansas isolates. Primers used for PCR amplification are as follows: BT1 forward and reverse (BT1F/BT1R); BT2F/R, and $\mathrm{BT} 3 \mathrm{~F} / \mathrm{R}$. The primer sequence and length of each amplicon were: BT1F (5'-CTCAGGATCTCAACTTCTTGCTTCC-3'), BT1R (5' GTAATGTCCCTTGGCCCAGTTG-3'), 806 bp; BT2F (5'CCGTCCATAATACGAGCTGCGG-3'), BT2R (5'GCCATCATGTTCTTCGGGTCG-3'), 795 bp; BT3F (5'GTTTCCCTGGTCAACTCAACTCC-3'), BT3R (5'CAACAATGCTTGCTGCCAATGAAG-3'), 805 bp (Fig. 1).

PCR amplification was carried out using Ex Taq (TaKaRa Bio Co., Mountain View, CA) thermostable proof-reading DNA polymerase and $25 \mathrm{pmol}$ of each primer per reaction. PCR amplification parameters consisted of $90^{\circ} \mathrm{C}$ for $5 \mathrm{~min}$, followed by 35 cycles of $90^{\circ} \mathrm{C}$ for $30 \mathrm{~s}$, a primer pair-specific temperature of $57.8^{\circ} \mathrm{C}$ for primer pairs BT1F/BT1R and BT2F/R; $59.0^{\circ} \mathrm{C}$ for $\mathrm{BT} 3 \mathrm{~F} / \mathrm{R}$, and $72^{\circ} \mathrm{C}$ for $90 \mathrm{~s}$; and ending with a final elongation step of $72^{\circ} \mathrm{C}$ for $5 \mathrm{~min}$. PCR products were electrophoresed on a $1 \%$ agarose gel to verify size, and all products were directly sequenced at the Kansas State University DNA Sequencing and Genotyping Facility. Sequences were analyzed using Geneious version 5.3.5 created by Biomatters (Auckland, New Zealand).

In the genomic sequence, bp number +977 relative to the ATG start codon was an adenosine in all four sensitive isolates and the sensitive reference isolate MB01 and a cytosine in all four resistant isolates, corresponding to a substitution of alanine for glutamic acid at codon 198 (E198A) in the resistant isolates (Fig. 1). There were no other sequence differences among all eight sequenced isolates. A representative $S$. homoeocarpa $\beta$ tubulin sequence was submitted to Genbank (accession KF765483). As noted above, mutations at codon 198 are the most commonly reported substitutions associated with resistance to $\mathrm{MBC}$ fungicides, and our findings are consistent with the prior report of a mutation at codon 198 (E198K) in one isolate of $S$. homoeocarpa (13), though with a different amino acid substitution. All other codons previously implicated in MBC fungicide resistance did not harbor mutations compared with the reference sequence. Many studies of MBC fungicide resistance in various fungi have focused only on sequence analysis of codons 


\section{BT1F}

$-103$

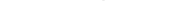
492 513

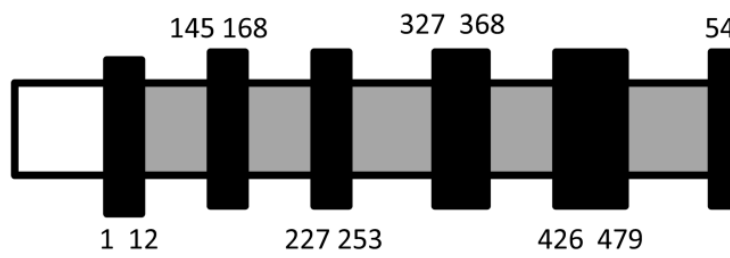
544

\section{4}

\section{FIGURE 1}

DNA sequence analysis of the $\beta$-tubulin gene in thiophanate-methyl sensitive and resistant Sclerotinia homoeocarpa isolates. The gene structure of the $S$. homoeocarpa $\beta$-tubulin gene is shown with exons (black) and introns (grey), DNA sequence coordinates relative to the ATG start codon, and the position of $P C R$ primer pairs BT1F/BT1R, BT2F/BT2R and BT3F/BT3R. The sequence differences between sensitive and resistant isolates are indicated. The resistant isolates all harbored a substitution of alanine (Ala) for glutamic acid (Glu) at codon 198 (E198A). Sequences were determined for four sensitive isolates (isolates DS4, DS5, and DS6 from site DCC and DS35 from site CBHCC) and four resistant isolates (isolates DS24 and DS31 from site CBHCC, DS58 from site MCC, and DS66 from site QRCC).

167-241. The extreme 5' end of the $\beta$-tubulin gene, including codon six which has been associated with MBC resistance, has been difficult to analyze due to the presence of a very short first exon and a relatively large first intron, which lacks conservation of sequence and length. The entire $\beta$-tubulin gene of $S$.

homoeocarpa has not previously been sequenced in full in a study comparing resistant and sensitive isolates.

\section{CONCLUSIONS}

In this first examination of thiophanate-methyl sensitivity in $S$. homoeocarpa in Kansas, 65 of the 82 isolates were resistant. In vitro sensitivity corresponded to fungicide efficacy in greenhouse trials, with resistant isolates causing blighting on thiophanatemethyl treated plants equivalent to the blighting in non-treated controls. An E198A mutation (substitution of alanine for glutamic acid at codon 198) was identified in the $\beta$-tubulin sequence of resistant isolates. Golf course superintendents should consider resistance to this active ingredient when formulating their fungicide management strategies. 


\section{ACKNOWLEDGMENTS}

The authors greatly appreciate the unpublished sequence information of isolate MB01 provided by Dr. Lane Tredway and other background information about MB01 provided by Dr. Michael Boehm. We acknowledge C.C. Hunter for assistance with molecular techniques. The authors also would like to thank the Kansas Turfgrass Foundation and the Kansas Golf Course Superintendents Association for providing financial support and the superintendents who assisted with collection of isolates. This manuscript is contribution 14-063-J of the Kansas Agricultural Experiment Station.

\section{LITERATURE CITED}

1. Bishop, P., Sorochan, J., Ownley, B. H., Samples, T. J., Windham, A., Windham, M. T., and Trigiano, R. N. 2008. Resistance of Sclerotinia homoeocarpa to iprodione, propiconazole, and thiophanate-methyl in Tennessee and Northern Mississippi. Crop Sci. 48:1615-1620.

2. Burpee, L. L. 1997. Control of dollar spot of creeping bentgrass caused by an isolate of Sclerotinia homoeocarpa resistant to benzimidazole and demethylation-inhibitor fungicides. Plant Dis. 81:1259-1263.

3. Chen, F., Liu, X., and Schnabel, G. Field strains of Monilinia fructicola resistant to both $\mathrm{MBC}$ and DMI fungicides isolated from stone fruit orchards in the Eastern United States. Plant Dis. 97:1063-1068.

4. Couch, H. B. 1995. Pages 65-69 in: Diseases of Turfgrasses, 3rd Edition. Krieer Publ., Malabar, FL.

5. Detweiler, A. R., Vargas, J. M. Jr., and Danneberger, T. K. 1983. Resistance of Sclerotinia homoeocarpa to iprodione and benomyl. Plant Dis. 67:627-630.

6. DeVries, R. E., Trigiano, R. N., Windham, M. T., Windham, A. S., Sorochan, J. C., Rinehart, T. A., and Vargas, J. M. 2008. Genetic analysis of fungicide-resistant Sclerotinia homoeocarpa isolates from Tennessee and Northern Mississippi. Plant Dis. 92:83-90.

7. Glass, N. L., and Donaldson, G. C. 1995. Development of primer sets designed for use with the PCR to amplify conserved genes from filamentous ascomycetes. Appl. Environ. Microbiol. 61:1323-1330.

8. Gonzalez, B. R., and Kennelly, M. M. 2012. Sensitivity of Kansas isolates of Sclerotinia homoeocarpa to boscalid. Plant Health Progress doi:10.1094/PHP-2012-0402-01-RS.

9. Jo, Y.-K., Chang, S. W., Boehm, M., and Jung, G. 2008. Rapid development of fungicide resistance by Sclerotinia homoeocarpa on turfgrass. Phytopathology 98:1297-1304.

10. Jo, Y.-K., Niver, A. L., Rimelspach, J. W., and Boehm, M. J. 2006. Fungicide sensitivity of Sclerotinia homoeocarpa from golf courses in Ohio. Plant Dis. 90:801-813.

11. Jung, M. K., Wilder, I. B., and Oakley, B. R. 1992. Amino acid alteration in the benA ( $\beta$-tubulin) gene of Aspergillus nidulans that confer benomyl resistance. Cell Motil. Cytoskeleton 22:170-174.

12. Kennelly, M. M., and Wolf, R. E., 2009. Effect of nozzle type and water volume on dollar spot control in greens-height creeping bentgrass. Applied Turfgrass Science. doi:10.1094/ATS-2009-0921-01-RS.

13. Koenraadt, H., Somerville, S. C., and Jones, A. L. 1992. Characterization of mutations in the beta-tubulin gene of benomyl-resistant field strains of Venturia inaequalis and other plant pathogenic fungi. Phytopathology 82:1348-1354.

14. Latin, R. 2011. A Practical Guide to Turfgrass Fungicides. American Phytopathological Society, St. Paul, MN.
15. Ma, Z., and Michailides, T. J. 2005. Advances in understanding molecular mechanisms of fungicide resistance and molecular detection of resistant genotypes in phytopathogenic fungi. Crop Prot. 24:853-863.

16. Ma, Z., Yoshimura, M. A., Holtz, B. A., and Michailides, T. J. 2004. Characterization and PCR-based detection of benzimidazole-resistant isolates of Monilinia laxa in California. Pest Manag. Sci. 61:449-457.

17. Ma, Z., Yoshimura, M. A., and Michailides, T. J. 2003. Identification and characterization of benzimidazole resistance in Monilinia fructicola from stone fruit orchards in California. Appl. Environ. Microbiol. 69:71457152.

18. May, G. S., Tsang, M. L. S., Smith, H., Fidel, S., and Morris, N. R. 1987. Aspergillus nidulans beta-tubulin genes are unusually divergent. Gene 55:231-243

19. McDonald, S. J., Dernoeden, P. H., and Bigelow, C. A. 2006. Dollar spot control in creeping bentgrass as influenced by fungicide spray volume and application timing. Applied Turfgrass Science doi:10.1094/ATS2006-0531-01-RS.

20. McKay, G. J., Egan, D., Morris, E., and Brown, A. E. 1998. Identification of benzimidazole resistance in Cladobotryum dendroides using a PCRbased method. Mycol. Res. 102:671-676

21. Miller, G. L., Stevenson K. L., and Burpee, L. L. 2002. Sensitivity of Sclerotinia homoeocarpa isolates to propiconazole and impact on control of dollar spot. Plant Dis. 86:1240-1246.

22. Oakley, B. R. 2004. Tubulins in Aspergillus nidulans. Fungal Genet. Biol. 41:420-427.

23. Orshinsky, A. M., Hu, J., Opiyo, S. O., Reddyvari-Channarayappa, V., Mitchell, T. K., and Boehm, M. J. 2012. RNA-Seq analysis of the Sclerotinia homoeocarpa-creeping bentgrass pathosystem. PLoS ONE 7(8):e41150. doi:10.1371/journal.pone.0041150.

24. Park, S. Y., Jung, O. J., Chung, Y. R., and Lee, C. W. 1997. Isolation and characterization of a benomyl-resistant form of beta-tubulin-encoding gene from the phytopathogenic fungus Botryotinia fuckeliana. Mol. Cells 7:104-109.

25. Putman, A. I., Jung, G., and Kaminski, J. E. 2010. Geographic distribution of fungicide-insensitive Sclerotinia homoeocarpa isolates from golf courses in the northeastern United States. Plant Dis. 94:186195.

26. Shepard, D., Agnew, M., Fidanza, M., Kaminski, J., and Dant, L. 2006. Selecting nozzles for fungicide spray applications: Using the right nozzle may save your grass. Golf Course Manage. June:83-88.

27. Smiley, R. W., Dernoeden, P. H., and Clarke, B. B. 2005. Compendium of Turfgrass Diseases, 3rd Edition. The American Phytopathological Society, St. Paul, MN.

28. Vincelli, P., and Dixon, E. 2007. Does spray coverage influence fungicide efficacy against dollar spot? Applied Turfgrass Science doi:10.1094/ATS2007-1218-01-RS

29. Vincelli, P., and Munshaw, G. 2013. Chemical control of turfgrass diseases. Coop. Ext. Publ. PPA-1. University of Kentucky, Lexington.

30. Warren, C. G., Sanders, P., and Cole, H. 1974. Sclerotinia homoeocarpa tolerance to benzimidazole configuration fungicides. Phytopathology 64:1139-1142.

31. Wong, F. P., Cerda, K. A., Hernandex-Martinez, R., and Midland, S. L. 2008. Detection and characterization of benzimidazole resistance in California populations of Colletotrichum cereale. Plant Dis. 92:239-246.

32. Young, J. R., and Tomaso-Peterson, M. 2010. Two mutations in $\beta$-tubulin 2 gene associated with thiophanate-methyl resistance in Colletotrichum cereale isolates from creeping bentgrass in Mississippi and Alabama. Plant Dis. 94:207-212. 